\title{
Short Communication: The potential of Sulfate Reducing Bacteria of ex-coal mine sediment pond as sulfate reducing agents of acid land in Samarinda, Indonesia
}

\author{
EKO KUSUMAWATI ${ }^{1, \bullet}$, SUDRAJAT $^{2}$, IKA PURNAMASARI ${ }^{3}$, BINA CRISTYANTI PANGGABEAN ${ }^{1}$, \\ MAIDA APRIYANTI ${ }^{1}$ \\ ${ }^{1}$ Laboratory of Microbiology and Molecular Genetics, Department of Biology, Faculty of Mathematics and Natural Sciences, Universitas Mulawarman. \\ Samarinda 75123, East Kalimantan, Indonesia. "email: eko.kusumawati11@ gmail.com \\ ${ }^{2}$ Laboratory of Animal Anatomy and Microtechnique, Department of Biology, Faculty of Mathematics and Natural Sciences, Universitas Mulawarman. \\ Samarinda 75123, East Kalimantan, Indonesia \\ ${ }^{3}$ Laboratory of Economics and Business, Department of Mathematics, Faculty of Mathematics and Natural Sciences, Universitas Mulawarman. \\ Samarinda 75123, East Kalimantan, Indonesia
}

Manuscript received: 20 May 2017. Revision accepted: 9 September 2017.

\begin{abstract}
Kusumawati E, Sudrajat, Purnamasari I, Panggabean BC, Apriyanti M. 2017. Short Communication: The potential of Sulfate Reducing Bacteria of ex-coal mine sediment pond as sulfate-reducing agents of acid land in Samarinda, Indonesia. Bonorowo Wetlands 7: 79-82. The study aims to determine the effect of $\mathrm{pH}$ medium on the growth of sulfate-reducing bacteria taken from the e-coal mine sediment pond and determine its potential as a reducing sulfate agent of acid ex-coal mine land in Samarinda East Kalimantan, Indonesia. This study used six SRB isolated from an ex-coal mine sediment pond in Samarinda. The SRB potency test in reducing sulfate was conducted by growing the SRB on Postgate liquid medium at different pHs of 2, 4, and 6 by adding acid soils on each treatment. The results showed that sulfate reducing bacteria isolated from ex-coal mine sediment pond in Samarinda, i.e., sp.1 (Desulfococcus sp.), sp.2 (Desulfotomaculum sp.), sp.3 (Desulfobacter sp.), sp.4 (Desulfobulbus sp.), sp.5 (Desulfobacterium sp.) and sp.6 (Desulfotomaculum sp.) had potential as sulfate reducing agent of acid land. The efficiency of sulfate reduction was $89 \%, 91 \%$, and $91 \%$ in the $\mathrm{pH}$ of 2,4 , and 6 , respectively. This indicated that the highest sulfate reduction is in the medium with $\mathrm{pH} 4$ and 6 . In addition, sp.5 (Desulfobacterium sp.) growing on medium at $\mathrm{pH} 4$ had the best sulfate reduction efficiency (93\%) compared with other SRB isolates.
\end{abstract}

Keywords: $\mathrm{pH}$ of the medium, sulfate reducing bacteria, acid land

\section{INTRODUCTION}

Mining activities such as coal mining can provide economic benefits and cause environmental and soil ecosystems damages (Tala'ohu et al., 1995). One element of the causes of the impact is the generated waste as a byproduct of the remnant of the mining and processing, which are often in large volume and various kinds. United Nations Environment Programme (UNEP) classifies the impacts of mining activities, including the destruction of habitat and biodiversity at the mine site, the landscape change or loss of land use, and B3 waste and chemicals (Fahruddin 2010). The most severe mining activity problem is the phenomenon of acid mine drainage (AMD) or acid rock drainage (ARD) due to the oxidation of sulfur minerals. This will give a series of interrelated effects, namely decreasing $\mathrm{pH}$, disturbing the availability and the balance of soil nutrients, and increasing the solubility of micronutrients which generally is a metal element (Havlin et al. 1999).

One environmentally friendly method is bioremediation, namely, a process to restore the environment using microorganisms as contaminants eliminating. A group of microbes that can improve the quality of post-mine land is sulfate-reducing bacteria (SRB). In metabolic activities, SRB can convert sulfate to H2S. This gas will immediately bind to the metals found in many post-mining land and precipitate in the form of metal sulfides reductive (Hards and Higgins 2004). However, the main problem often encountered in applying microorganisms for bioremediation is the decrease or the loss of potential microbial. To improve the effectiveness of microorganisms in bioremediation, the following two strategies can be done. First, bio-stimulation is a technique to add specific nutrients to stimulate the activity of local (indigenous) microbes. Atlas and Bartha (1992) stated that the biosimulation process has successfully controlled the oil spills in water and the contamination of hydrocarbons (PAHs) in the soil. Lieberg and Cutright (1999) stated that nutrients often used in this technique are phosphorus and nitrogen. Second, bio-augmentation is a technique to introduce specific microbes in the remediated area. In addition, environmental influences such as $\mathrm{pH}$, temperature, and soil moisture were also very influential in determining the success of the bioremediation process.

Based on the introduction, the problem in this research is how the influence of $\mathrm{pH}$ of the medium on the sulfate reduction activity of sulfate reducing bacteria isolated from 
ex-coal mine sediment pond in Samarinda on acid land (TMT) on the location of the ex-coal mine is. The purpose of this study was to determine the effect of medium $\mathrm{pH}$ on the potential sulfate reducing bacteria isolated from ex-coal mine sediment pond in Samarinda as a sulfate reducing agent in acid land (TMT) on the location of the ex-coal mining is. The obtained information will develop bacteria as a potential environmentally friendly bioremediation agent.

\section{MATERIALS AND METHODS}

\section{Sampling}

Sulfate-reducing bacteria (SRB) were isolated from an ex-coal mine sediment pond in Samarinda, East Kalimantan. Bacteria were isolated on Postgate liquid medium (Atlas and Park, 1993) containing (g/l) Na lactate (3.5), $\quad \mathrm{Mg} . \mathrm{SO}_{4} \quad$ (2.0), $\quad \mathrm{NH}_{4} \mathrm{Cl} \quad(0.2), \quad \mathrm{KH}_{2} \mathrm{PO}_{4} \quad(0.5)$, $\mathrm{FeSO}_{4} .7 \mathrm{H}_{2} \mathrm{O}(0.5)$ and $\mathrm{pH} 4$ and sterilized at $121^{\circ} \mathrm{C}$ with 1 atmosphere pressure for 15 minutes. SRB growth was characterized by the emergence of colonies in dark brown to black at the bottom of the tube.

\section{Sulfate-reducing bacteria activity test on liquid media}

Six SRB isolates result from the isolation of bacteria from ex-coal mine land in Samarinda. The isolates comprised of a mixture of six isolates based on the early identification, i.e., sp.1 (Desulfococcus sp.), sp.2 (Desulfotomaculum sp.), sp.3 (Desulfobacter sp.), sp.4 (Desulfobulbus sp.), sp.5 (Desulfobacterium sp.) and sp.6 (Desulfotomaculum sp.). Each pure isolate SRB (1 ml) was inoculated into a liquid Postgate medium enriched with $2 \mathrm{~N}$ sulfuric acid solution as much as $5 \%(\mathrm{v} / \mathrm{v})$. The cultures were incubated in $25 \mathrm{ml}$ tubes filled up to total volume. Each SRB isolate was used to treat with a consortium of all bacterial treatments. Experiments were carried out in a completely randomized design with three replications. The sulfate measurements were done at the beginning and twenty days of treatment. The control group was treated with Postgate $\mathrm{B}$ medium enriched with $2 \mathrm{~N}$ sulfuric acid solution as much as $5 \%(\mathrm{v} / \mathrm{v})$ without $\mathrm{SRB}$ inoculation. The efficiency of each treatment was calculated using the formula stated by Widyati (2006), namely:

(Initial sulfate concentration) - (final sulfate concentration) x 100\% (Initial concentration)

\section{Sulfate-reducing bacteria activity test against acid ex- coal mine soil with $\mathrm{pH}$ of $2,4,6$}

The composition of bacteria used in the trial experiments test was similar to SRB in Postgate liquid media. SRB isolates used in this study are maintained in a Postgate liquid medium. Each of these pure SRB isolates (1 $\mathrm{ml}$ ) was inoculated into a liquid Postgate media with different $\mathrm{pH}$, i.e., $\mathrm{pH} 2,4$, and 6. Each media was previously filled with 5 grams of acid ex-coal mine soils. The cultures were incubated in a $10 \mathrm{ml}$ screw-capped tube filled to the brim. Each SRB isolate was used to treat with a consortium of all bacterial treatments. Experiments were carried out in a completely randomized design with three replications. The measurements of $\mathrm{pH}$ and sulfate were done at the beginning of treatment and after twenty days of treatment. The control group was treated with Postgate B medium enriched with $2 \mathrm{~N}$ sulfuric acid solution as much as $5 \%(\mathrm{v} / \mathrm{v})$ without SRB inoculation. The efficiency of each treatment was calculated using the formula stated by Widyati (2006), namely:

(Initial sulfate concentration) - (final sulfate concentration) x 100\% (Initial concentration)

\section{RESULTS AND DISCUSSION}

SRB activity test results on the liquid Postgate media can be seen in Table 1. Table 1 shows that the treatment not inoculated with SRB sulfate concentrations only slightly decreased while the sulfate in the treatment inoculated with SRB sulfate concentrations varied on the 20th day after incubation. When it was calculated with the formula of efficiency of Widyati $(2006,2007)$, the lowest efficiency value was obtained at sp.1 and sp.3 with the amount of $74 \%$, while the highest efficiency value was obtained at sp.5 with $91 \%$, but on the controls which were not inoculated with SRB, the efficiency only decreased by $1 \%$ within 20 days. In this study, the sulfate concentration decreased because the SRB can use sulfate as an electron acceptor for metabolic activities (Doshi 2006). Because the sulfur accepts electrons, it will change to sulfide so that its concentration in the culture decreases.

SRB activity test was also conducted on samples of coal mine acid soil to measure the content of sulfate in the soil using ex-coal mine soil with varying $\mathrm{pH}$, namely $\mathrm{pH} 2,4$, and 6 . The measurement results on sulfate content changes on ex-coal mine land by SRB activity can be seen in Table 2.

Data in Table 2 show that sulfate reduction occurred in all treatments. The efficiency test on sulfate reduction is done by SRB activity in reducing ex-coal mine sulfuric acid soil after 20 days of treatment. It results that it is more significant at $\mathrm{pH} 4$ and 6 than at $\mathrm{pH} 2$. The sulfate reduction efficiencies ranging from $\mathrm{pH} 2, \mathrm{pH} 4, \mathrm{pH} 6$ are respectively $89 \%, 91 \%$, and $91 \%$. This shows that sulfate reduction is most significant at $\mathrm{pH} 4$ and 6 . Table 1 also shows that the controls remain sulfate reduction occurred when the control contained only sterile media and acid soil, coal mines without getting additional isolates SRB. This indicates that in acid soil samples, there is also the content of indigenous sulfate-reducing bacteria in those samples. It was alleged that the sulfate-reducing bacteria are more efficient to reduce sulfate at $\mathrm{pH} 2$ than at $\mathrm{pH} 4$ and $\mathrm{pH} 6$, so the efficiency of the control sulfate reduction treatment at $\mathrm{pH} 2$ is $92 \%$, which is higher than at $\mathrm{pH} 4(87 \%)$ and $\mathrm{pH} 6$ $(91 \%)$. 
Table 1. The concentration of sulfate at the beginning and the end of the test was done by the activity of sulfate to reduce bacteria in a liquid medium Postgate

\begin{tabular}{|c|c|c|c|c|}
\hline Treatment & $\begin{array}{c}\text { Initial sulfate concentration in } \\
\text { the medium }(\mathrm{mg} / \mathrm{L})\end{array}$ & $\begin{array}{c}\text { Final sulfate } \\
\text { concentration }(\mathrm{mg} / \mathrm{L})\end{array}$ & $\begin{array}{c}\text { Reduction of } \\
\text { sulfate (mg/L) }\end{array}$ & $\begin{array}{c}\text { Efficiency } \\
(\%)\end{array}$ \\
\hline Control & 128,668 & 127,405 & 1,263 & $1 \%$ \\
\hline Sp.1 (Desulfococcus sp.) & 127,835 & 33,450 & 94,385 & $74 \%$ \\
\hline Sp.2 (Desulfotomaculum sp.) & 128,630 & 31,479 & 97,151 & $76 \%$ \\
\hline Sp.3 (Desulfobacter sp.) & 126,878 & 32,704 & 94,174 & $74 \%$ \\
\hline Sp.4 (Desulfobulbus sp.) & 129,365 & 32,944 & 96,421 & $75 \%$ \\
\hline Sp.5 (Desulfobacterium sp.) & 128,043 & 12,023 & 116,020 & $91 \%$ \\
\hline Sp.6 (Desulfotomaculum sp.) & 127,772 & 14,092 & 113,680 & $89 \%$ \\
\hline Consortium & 129,507 & 32,129 & 97,377 & $75 \%$ \\
\hline
\end{tabular}

Table 2. Initial to final sulfate concentration on sulfate reducing bacteria activity test against coal mine acid soil with pH medium using different liquid Postgate medium

\begin{tabular}{|c|c|c|c|c|c|}
\hline pH & Treatment & $\begin{array}{c}\text { Initial sulfate } \\
\text { concentration in the } \\
\text { medium }(\mathrm{mg} / \mathrm{L})\end{array}$ & $\begin{array}{c}\text { Final sulfate } \\
\text { concentration } \\
(\mathrm{mg} / \mathrm{L}) \\
\end{array}$ & $\begin{array}{c}\text { Reduction of } \\
\text { sulfate }(\mathrm{mg} / \mathrm{L})\end{array}$ & Efficiency $(\%)$ \\
\hline \multirow[t]{9}{*}{2} & Control & 202,437 & 15,561 & 186,876 & 92 \\
\hline & Sp.1 (Desulfococcus sp.) & 220,080 & 24,090 & 195,990 & 89 \\
\hline & Sp.2 (Desulfotomaculum sp.) & 212,917 & 23,106 & 189,810 & 89 \\
\hline & Sp.3 (Desulfobacter sp.) & 234,273 & 23,726 & 210,547 & 90 \\
\hline & Sp.4 (Desulfobulbus sp.) & 216,287 & 21,489 & 194,798 & 90 \\
\hline & Sp.5 (Desulfobacterium sp.) & 215,313 & 29,115 & 186,199 & 86 \\
\hline & Sp.6 (Desulfotomaculum sp.) & 222,023 & 28,318 & 193,705 & 87 \\
\hline & Consortium & 210,480 & 20,580 & 189,900 & 90 \\
\hline & & & & & 89 \\
\hline \multirow[t]{9}{*}{4} & Control & 196,563 & 24,627 & 171,936 & 87 \\
\hline & Sp.1 (Desulfococcus sp.) & 224,930 & 19,381 & 205,549 & 91 \\
\hline & Sp.2 (Desulfotomaculum sp.) & 207,207 & 17,841 & 189,366 & 91 \\
\hline & Sp.3 (Desulfobacter sp.) & 212,080 & 18,229 & 193,851 & 91 \\
\hline & Sp.4 (Desulfobulbus sp.) & 205,117 & 15,867 & 189,250 & 92 \\
\hline & Sp.5 (Desulfobacterium sp.) & 219,733 & 16,313 & 203,421 & 93 \\
\hline & Sp.6 (Desulfotomaculum sp.) & 249,217 & 22,382 & 226,834 & 91 \\
\hline & Consortium & 215,213 & 23,404 & 191,809 & 89 \\
\hline & & & & & 91 \\
\hline \multirow[t]{9}{*}{6} & Control & 213,857 & 19,319 & 194,538 & 91 \\
\hline & Sp.1 (Desulfococcus sp.) & 206,230 & 21,570 & 184,660 & 90 \\
\hline & Sp.2 (Desulfotomaculum sp.) & 248,897 & 22,241 & 226,656 & 91 \\
\hline & Sp.3 (Desulfobacter sp.) & 189,877 & 19,147 & 170,730 & 90 \\
\hline & Sp.4 (Desulfobulbus sp.) & 207,483 & 15,999 & 191,484 & 92 \\
\hline & Sp.5 (Desulfobacterium sp.) & 189,453 & 16,898 & 172,555 & 91 \\
\hline & Sp.6 (Desulfotomaculum sp.) & 202,990 & 15,891 & 187,099 & 92 \\
\hline & Consortium & 200,970 & 15,153 & 185,817 & 92 \\
\hline & & & & & 91 \\
\hline
\end{tabular}

In making sulfate reduction, SRB uses sulfate as an energy source, i.e., as an electron acceptor, and uses organic materials as a carbon source (C). The carbon acts as a donor, the electrons in the metabolism, and the cell's building blocks (Groudev et al. 2001). Djurle (2004) adds that the SRB uses electron donor $\mathrm{H}_{2}$ and the $\mathrm{C}$ source $\left(\mathrm{CO}_{2}\right)$, obtained from organic materials. The reaction of sulfate reduction by SRB, according to Van Houten et al. (1994, 1995), is as follows:

$$
\mathrm{SO}_{4}{ }^{2-}+\mathrm{H}_{2}+2 \mathrm{H}+\rightarrow \mathrm{H}_{2} \mathrm{~S}+4 \mathrm{H}_{2} \mathrm{O}
$$

In this research, the initial $\mathrm{pH}$ medium used is 2,4 , and 6 ; after being treated with the increase in the $\mathrm{pH}$, it ranges 5-6. This shows that the SRB effectively increases the $\mathrm{pH}$ in each treatment. This occurrence may be because sulfuric acid is so strong that adding this compound into the environment will influence acidity $(\mathrm{pH})$. The more the reduction of sulfate, the higher the $\mathrm{PH}$. Increasing $\mathrm{pH}$ for SRB activity reducing the sulfate will have a double impact, i.e., to produce $\mathrm{H}_{2} \mathrm{~S}$ and bicarbonate ion (HCO). $\mathrm{H}_{2} \mathrm{~S}$ results from reducing sulfate (sulfate decreases, the $\mathrm{pH}$ will increase), and bicarbonate acts to increase the $\mathrm{pH}$ 
(Frank 2000). Based on the normality test to find out whether a value is a significantly different comparator or equal to the average value of each treatment, if the sample average sig $<0.05$, there were no significant differences in the samples with comparative values, and the data could not be received. The normality test showed abnormal results, so a non-parametric data analysis was used. The Kruskal-Wallis test analyzed data to analyze the sulfate reduction using a single factor, namely $\mathrm{pH}$ or SRB course. The test results showed that the sulfate reduction in $\mathrm{pH}$ or SRB treatment alone is not significantly different because sig is $>0.05$, and the data is rejected. Then, the data analysis was done by Friedman test to determine the effect of treatment in two factors: $\mathrm{pH}$ and SRB. The results of the Friedman test showed that the reduction of sulfate to the treatment of two factors, namely $\mathrm{pH}$ and SRB, was significantly different because sig was $<0.05$.

In conclusion, after doing this research, we concluded that six isolates of sulfate reducing bacteria isolated from ex-coal mine sediment pond in Samarinda, namely sp. 1 (Desulfococcus sp.), sp.2 (Desulfotomaculum sp.), sp.3 (Desulfobacter sp.), sp.4 (Desulfobulbus sp.), sp.5 (Desulfobacterium sp.) and sp.6 (Desulfotomaculum sp.) have potential as sulfate reducing agent in ex-coal mine acid soil (TMT) with efficiency sulfate reduction ranging from $\mathrm{pH} 2, \mathrm{pH} 4, \mathrm{pH} 6$ respectively $89 \%, 91 \%$, and $91 \%$. This indicates that the sulfate reduction is highest in the medium with $\mathrm{pH} 4$ and 6. It is also noted that sp.5 (Desulfobacterium sp.) on medium with $\mathrm{pH} 4$ has the best ability of sulfate reduction efficiency compared to other SRB isolates at $93 \%$. These results align with the Postgate activity test on sulfate reduction in liquid media, showing that treatment with sp.5 (Desulfobacterium sp.) gives the best results, i.e., $91 \%$ compared with other treatments.

\section{ACKNOWLEDGEMENTS}

Thanks to the Faculty of Mathematics and Natural Sciences and LP2M, Universitas Mulawarman, Samarinda, Indonesia, for all facilities and assistance of research that have been given so that research can be undergone.

\section{REFERENCES}

Atlas RM, Bartha R. 1992. Hydrocarbon biodegradation and oil spill bioremediation. In: Marshall KC (ed) Microbial Ecology. Vol. 12. Plenum Press. New York, USA. DOI: 10.1007/978-1-4684-7609-5_6.

Djurle C. 2004. Development of Model for Simulation of Biological Sulphate Reduction with Hydrogen as Energy Source. [Thesis]. Department of Chemical Engineering, Lund Institute of Technology, The Netherlands.

Doshi SM. 2006. Bioremediation of Acid Rock Drainage using Sulfate Reducing Bacteria. U.S. Environmental Protection Agency Office of Solid Waste and Emergency Response Office of Superfund Remediation and Technology Innovation, Washington, D.C.

Fahruddin. 2010. Bioteknologi Lingkungan. Penerbit Alfabeta, Bandung. [Indonesian]

Frank F. 2000. Bioremediation by sulfate reducing bacteria of acid mine drainage. Department of Environmental Sciences, UC Berkeley, CA, USA.

Groudev SN, Komnitsas K, Spasova II, Paspaliaris I. 2001. Treatment of AMD by a natural wetland. Miner Eng 12: 261-270. DOI: 10.1016/S0892-6875(99)00004-7.

Hards BC, Higgins JP. 2004. Bioremediation of Acid Rock Drainage Using SRB. Jacques Whit Environment Limited, Ontario.

Havlin JL, Beaton JD, Tisdale SL, Nelson WL. 1999. Soil Fertility and Fertilizers An Introduction to Nutrient Management. 6 th ed. Prentice Hall, Upper Saddle River, New Jersey.

Lieberg EW, Cutright TJ. 1999. The investigation of enhanced bioremediation through the addition of macro dan micro nutrisis in PAHs contaminated soil. J Intl Biodet Biodegrad 44 (1): 55-64. DOI: 10.1016/S0964-8305(99)00060-8.

Tala'ohu SH, Moersidi S, Sukristiyonubowo, Gunawan S. 1995. Sifat fisikokimia tanah timbunan batubara (PT BA) di Tanjung Enim, Sumatera Selatan. Prosiding Pertemuan Pembahasan dan Komunikasi Hasil Penelitian Tanah dan Agroklimat. Buku IV. Bidang Konservasi Tanah dan Air serta Agroklimat. Puslitbangtanak. Cisarua, 26-28 September 1995. [Indonesian]

van Houten RT, Hulshoff Pol LW, Lettinga G. 1994. Biological sulphate reduction using gas-lift reactors fed with hydrogen and carbon dioxide as energy and carbon source. Biotechnol Bioeng 44 (5): 586594. DOI: 10.1002/bit.260440505.

van Houten RT, van der Spoel H, van Aelst AC, Hulshoff Pol LW, Lettinga G. 1995b. Biological sulfate reduction using synthesis gas as energy and carbon source. Biotechnol Bioeng 50 (2): 136-144. DOI: 10.1002/(SICI)1097-0290(19960420)50:2<136::AID-BIT3>3.0.CO;2-N.

Widyati E. 2006. Bioremediasi Tanah Pasca tambang Batubara dengan Sludge Industri Kertas untuk Memacu Revegetasi Lahan. [Disertasi]. Sekolah Pascasarjana IPB. Bogor. [Indonesian]

Widyati E. 2007. Pemanfaatna bakteri pereduksi sulfat untuk bioremediasi tanah bekas tambang batubara. Biodiversitas 8 (4): 283-286. DOI: 10.13057/biodiv/d080408. 